УДК 347.962

DOI https://doi.org/10.51989/NUL.2021.4.43

\title{
ІМУНIТЕТ СУДДІВ КОНСТИТУЦІЙНОГО СУДУ УКРАЇНИ: ГАРАНТІЯ НЕЗАЛЕЖНОСТІ ЧИ СПОСІБ УНИКНЕННЯ ВІДПОВІДАЛЬНОСТІ?
}

\author{
Яцкевич Дмитро Сергійович,
}

аспірант кафедри судоустрою та прокурорської діяльності

Національного юридичного університету імені Ярослава Мудрого

29 грудня 2020 року на підставі клопотання тимчасово виконуючого обов'язки Генерального прокурора України Президент України видав Указ № 607/2020 про відсторонення від посади судді Конституційного Суду України Олександра Тупицького строком на два місяці. Таким чином, вперше в історії України Президент скористався повноваженнями, передбаченими частиною третьою статті 154 Кримінального процесуального кодексу України, у відношенні судді Конституційного Суду України. Цей крок викликав досить палкі дискусії в юридичній спільноті. Адже Конституція України не наділяє Президента правом «відсторонення від посади судді Конституційного Суду». Крім того, слід звернути увагу, що ні в Конституції України, ні в законі України «Про Конституційний Суд України», ні в регламенті Конституційного Суду не врегульовано питання тимчасового відсторонення від посади судді Конституційного Суду України.

В умовах трансформації українського суспільства та системи державної влади Конституційному Суду України належить вирішальна роль у забезпеченні верховенства Конституції, гарантуванні конституційного порядку та забезпеченні прав і свобод людини. Винятково важлива роль органу конституційного правосуддя зумовлює необхідність забезпечити його незалежність. Саме тому гарантії незалежності суддів Конституційного Суду України є вкрай важливим питанням сьогодення.

Статтю присвячено аналізу інституту імунітету суддів Конституційного Суду України. Досліджується питання конституційності указу Президента України щодо тимчасового відсторонення судді Конституційного Суду України від посади. Зосереджено увагу на імунітеті судді Конституційного Суду України в кримінальному провадженні.

Проаналізовано чинне законодавство України щодо можливості застосування до судді Конституційного Суду України такого заходу забезпечення кримінального провадження, як відсторонення від посади, виявлено в ньому відповідні прогалини та суперечності.

Ключові слова: гарантії незалежності суддів КСУ, імунітет суддів КСУ, відсторонення від посади, доктрина «прихованих повноважень».

\section{Yatskevych Dmytro. The immunity of judges of the Constitutional Court of Ukraine: is it a guarantee of independence or a way to avoid responsibility?}

On December 29, 2020, at the request of the Acting Prosecutor General of Ukraine, the President of Ukraine issued Decree № 607/2020 on the removal of Oleksandr Tupytskyi, a judge of the Constitutional Court of Ukraine, for a period of two months. Thus, for the first time in the history of Ukraine, the President used the powers provided for in part three of Article 154 of the Criminal Procedure Code of Ukraine in relation to a judge of the Constitutional Court of Ukraine. This step provoked quite heated discussions in the legal community. After all, the Constitution of Ukraine does not give the President the right to "remove from office a judge of the Constitutional Court". In addition, it should be noted that neither the Constitution of Ukraine, nor the Law of Ukraine "On the Constitutional Court of Ukraine", nor the Rules of Procedure of the Constitutional Court of Ukraine regulate the issue of temporary removal from office of a judge of the Constitutional Court of Ukraine.

In the context of the transformation of Ukrainian society and the system of state power, the Constitutional Court of Ukraine has a crucial role to play in ensuring the supremacy of the Constitution, guaranteeing the constitutional order and ensuring human rights and freedoms. The extremely important role of the body of constitutional justice determines the need to ensure its independence. That is why guarantees of the independence of judges of the Constitutional Court of Ukraine are an extremely important issue today. 
The article is devoted to the analysis of the institute of immunity of judges of the Constitutional Court of Ukraine. The issue of the constitutionality of the decree of the President of Ukraine on the temporary removal of a judge of the Constitutional Court of Ukraine from office is investigated. The focus is on the immunity of a judge of the Constitutional Court of Ukraine in criminal proceedings.

The current legislation of Ukraine on the possibility of applying to a judge of the Constitutional Court of Ukraine such a measure of criminal proceedings as removal from office was analyzed, the relevant gaps and contradictions were identified.

Key words: guarantees of independence of judges of the Constitutional Court of Ukraine, immunity of judges of the Constitutional Court of Ukraine, removal from office, the doctrine of "hidden powers".

Постановка проблеми. 29 грудня 2020 року Президент України видав Указ «Про відсторонення від посади судді Конституційного Суду України» № 607/2020. Підставою стало кримінальне провадження, в якому фігурує голова КСУ Тупицький Олександр Миколайович. Цей крок викликав досить палкі дискусії в юридичній спільноті. Адже Конституція України не наділяє Президента правом «відсторонення від посади судді Конституційного Суду». Більше того, ні Конституція, ні закон України «Про Конституційний Суд України» взагалі не передбачають можливості відсторонення судді Конституційного Суду від посади. Саме тому слід детально проаналізувати дану ситуацію та спробувати надати відповіді на такі запитання: чи не порушуються в цьому випадку гарантії незалежності суддів КС, надані їм Конституцією України та законом України «Про Конституційний Суд України»? Чи $€$ зазначений указ Президента конституційним? Чи взагалі до судді КСУ може бути застосований такий захід забезпечення кримінального провадження, як відсторонення від посади?

Аналіз останніх досліджень та публікацій. Проблематика імунітету суддів та їхньої відповідальності, юридичний зміст та обсяг яких на законодавчому рівні недостатньо визначений, нині $€$ особливо актуальною. Дана проблематика була предметом дослідження багатьох сучасних учених. Особливо слід виокремити праці таких науковців: І. Бабій, Л. Виноградова, А. Заєць, Д. Козак, О. Толочко, М. Савенко, В. Скомороха, П. Стецюк.

Метою статті $\epsilon$ розгляд актуальних питань імунітету суддів Конституційного Суду України, дослідження конституційності указу Президента України від 29 грудня 2020 року № 607/2020 та аналіз чинного законодавства України щодо можливості застосування до судді Конституційного Суду України такого заходу забезпечення кримі- нального провадження, як відсторонення від посади.

Виклад основного матеріалу. В умовах трансформації українського суспільства та системи державної влади Конституційному Суду України належить вирішальна роль у забезпеченні верховенства Конституції, гарантуванні конституційного порядку та забезпеченні прав і свобод людини. Винятково важлива роль органу конституційного правосуддя та завдання, які він виконує, зумовлюють необхідність забезпечити його незалежність, причому важливим $\epsilon$ забезпечення незалежності як органу (інституційні гарантії), так і його членів. Саме тому гарантії незалежності суддів Конституційного Суду України сьогодні $€$ вкрай важливим питанням [4].

Суддівський імунітет $\epsilon$ самостійним правовим інститутом, що складається із сукупності норм, які звільнюють суддів від виконання окремих юридичних обов'язків та які встановлюють особливі, ускладнені й відмінні від загальноприйнятих правові процедури притягнення до відповідальності 3 метою забезпечення конституційного статусу суддів і належного виконання ними своїх функцій. Суддівський імунітет $\epsilon$ загальновизнаним у сучасній світовій практиці демократизму функціонування судової влади в країнах із громадянським суспільством [5, с. 47]. Він $€$ важливою гарантією незалежного й об'єктивного здійснення своїх функцій суддями Конституційного Суду України (далі - КСУ), основним завданням якого $€$ гарантування верховенства Конституції України як основного закону держави на всій території України.

При цьому одним із найбільш актуальних та вельми дискусійних питань $\epsilon$ імунітет суддів у кримінальному процесі. Складність цього питання полягає саме в специфіці змісту суддівського імунітету та процесуального статусу суддів у кримінальному провадженні. Основною проблемою імунітету судді 
$\epsilon$ те, що, з одного боку, він служить гарантією, що особа, яка його має, буде захищена від необґрунтованого кримінального переслідування. А з іншого боку, надмірні законодавчі перешкоди для притягнення посадових осіб до відповідальності роблять часто неможливим об'єктивне всебічне розслідування, що у свою чергу не сприяє формуванню поважного ставлення громадян до закону і влади. За цих умов перед державою стоїть завдання якомога більш коректного врегулювання цієї сфери кримінальних процесуальних відносин з тим, щоб, з одного боку, забезпечити безперешкодне функціонування та діяльність усієї суддівської системи, а з іншого мінімізувати можливість зловживання представниками суддівського корпусу наданими державою гарантіями недоторканності [6].

Положення ст. 147 Конституції передбачають, що діяльність КСУ ґрунтується на принципах верховенства права, незалежності, колегіальності, гласності, обґрунтованості та обов'язковості ухвалених ним рішень і висновків [1]. 3-поміж цих принципів суттєве значення займає незалежність, яка стосується діяльності як самого КСУ, так і суддів КСУ.

Загальні гарантії незалежності суддів КСУ визначені ст. 149 Конституції та ст. 24 Закону «Про Конституційний Суд України». Окремі з цих гарантій відображені в КПК України, який регламентує безпосередню процедуру здійснення кримінального провадження. Наприклад, відповідно до п. 3 ч. 1 ст. 481 КПК повідомлення про підозру судді КСУ здійснюється Генеральним прокурором або його заступником [3].

При цьому слід звернути увагу, що ні в розділі XII Конституції, ні в законі про КСУ, ні в регламенті КСУ не врегульовано питання тимчасового відсторонення від посади судді КСУ у зв'язку з притягненням його до кримінальної відповідальності. У вказаних нормативно-правових актах лише визначаються питання припинення повноважень судді КСУ та його звільнення, які не охоплюють питання тимчасового відсторонення судді КСУ у зв'язку 3 набуттям ним статусу підозрюваного. Це $\epsilon$ нетотожні правові заходи, які мають різну мету, підстави застосування та порядок їх реалізації, що у свою чергу унеможливлює застосування до суддів КСУ по аналогії процедури, передбаченої законом про КСУ та регламентом КСУ щодо звільнення судді КСУ або припинення його повноважень за наявності на те законних підстав. Оскільки порядок кримінального провадження на території України визначається лише кримінальним процесуальним законодавством України (стаття 1 КПК), Закон України «Про Конституційний Суд України» не може і не повинен врегульовувати питання застосування заходів забезпечення кримінального провадження. У зв'язку із цим судді КСУ тимчасово відсторонюються від посади у зв'язку з притягненням до кримінальної відповідальності в порядку, передбаченому КПК.

Відсторонення від посади виступає одним із заходів забезпечення кримінального провадження, спрямованим на досягнення дієвості цього провадження, тобто воно застосовується з метою припинення кримінального правопорушення, припинення протиправної поведінки, запобігання протиправній поведінці особи, яка підозрюється або обвинувачується у вчиненні злочину i, перебуваючи на посаді, зможе знищити чи підробити речі або документи, що мають значення для досудового розслідування, незаконними способами впливати на свідків та інших учасників кримінального провадження або протиправно перешкоджати кримінальному провадженню іншим способом [7].

Загальні положення відсторонення від посади визначені ст. 154 КПК. Зокрема, в ній вказується, що відсторонення від посади може бути здійснено щодо особи, яка підозрюється або обвинувачується у вчиненні злочину (ч. 1).

У цьому контексті потрібно враховувати положення ч. 3 ст. 154 КПК, яка передбачає, що питання про відсторонення від посади осіб, що призначаються Президентом, вирішується Президентом на підставі клопотання прокурора в порядку, встановленому законодавством [3].

Частиною 1 ст. 155 КПК передбачено, що прокурор, слідчий за погодженням із прокурором має право звернутися до слідчого судді під час досудового розслідування або суду під час судового провадження із клопотанням про відсторонення особи від посади [3]. Таке клопотання повинно відповідати загальним вимогам, які передбачені у ч. 2 ст. 155 КПК.

При цьому гл. 14 КПК у ст. 155-1 передбачає спеціальний порядок відсторонення від посади судді від здійснення правосуддя у зв'язку з притягненням до кримінальної відповідальності та продовження 
строку такого тимчасового відсторонення, який застосовується виключно щодо суддів загальних судів. На цьому акцентував вітчизняний законодавець, визначаючи назву цієї статті [8]. Однак такий порядок не може застосовуватися щодо суддів КСУ, оскільки судді КСУ не здійснюють правосуддя, а уповноважені реалізовувати повноваження, передбачені ст. 7 закону про КСУ [2]. Конституція України визначає Конституційний Суд України як єдиний орган конституційної юрисдикції в Україні. Відповідно до ст. 147 Конституції України КСУ вирішує питання про відповідність Конституції законів України та в передбачених Конституцією випадках інших актів здійснює офіційне тлумачення Конституції, а також інші повноваження відповідно до Конституції [1]. Незважаючи на те, що Конституційний Суд містить у своїй назві слово «суд», однак вказаний державний орган не здійснює основоположну судову функцію - функцію правосуддя. КСУ $\epsilon$ особливим органом конституційного контролю, основним завданням якого $€$ гарантування верховенства Конституції України як основного закону держави на всій території України. Саме тому можна стверджувати, що КСУ як орган конституційної юрисдикції правосуддя в Україні не здійснює.

Слід погодитись, що ч. 3 ст. 154 КПК у найзагальніший спосіб визначає повноваження Президента відсторонити від посади в межах кримінального провадження. А саме $€$ вказівка, що глава держави має такі повноваження виключно щодо «осіб, що призначаються Президентом» та «на підставі клопотання прокурора в порядку, встановленому законодавством».

Правова доктрина справедливо наголошує на «особливості» статусу суддів КСУ. Проте КПК не передбачає жодних особливостей застосування заходів забезпечення кримінального провадження стосовно даної категорії посадовців, крім загального порядку щодо осіб, призначених на посади Президентом [8]. Перелік осіб, яких призначає на посади глава держави, визначений у ст. 106 Конституції, серед яких $€$ й судді КСУ. Однак у Конституції України прямо не передбачено повноваження Президента відстороняти від посади суддів КСУ. Отже, $\epsilon$ підстави вважати, що у Президента України відсутнє конституційне право відстороняти від посади суддю КСУ.

Однак у цій ситуації слід звернути увагу на доктрину «прихованих повноважень» глави держави, під якими розуміють повноваження глави держави, які не передбачені в Конституції, однак випливають з ії̈ змісту і стосуються особливостей його діяльності в екстраординарних ситуаціях. Перелік повноважень Президента визначено у ч. 1 ст. 106 Конституції, зокрема, згідно з п. 31 4. 1 даної статті Президент здійснює інші повноваження, визначені Конституцією. При цьому формулювання щодо повноважень глави держави слід сприймати у системному зв'язку з принципами та іншими конституційними нормами, якими визначається статус Президента України, зокрема його ролі як гаранта державного суверенітету, територіальної цілісності України, додержання Конституції України, прав і свобод людини і громадянина (частина друга статті 102 Конституції України) [9]. Саме тому необхідно з'ясувати: чи справді повноваження Президента визначаються лише текстом статті 106 Конституції України і яким $\epsilon$ їх обсяг? У цьому питанні $\epsilon$ два аспекти: а) чи може закон України покладати на Президента України додаткові повноваження (права і обов'язки), тобто такі, які письмово не сформульовані в переліку його повноважень у частині першій статті 106 Конституції України? б) як слід розуміти обсяг конституційних повноважень Президента України, зазначених у частині першій статті $106 \mathrm{Koн-}$ ституції України?

Спочатку проаналізуємо перший аспект. Звернемо увагу на частину другу статті 19 КонституціїУкраїни, якапередбачає: «Органи державної влади та органи місцевого самоврядування, їх посадові особи зобов'язані діяти лише на підставі, в межах повноважень та у спосіб, що передбачені Конституцією та законами України». Оскільки Президент України $\epsilon$ органом державної влади, це означає, що він зобов'язаний діяти на підставі, в межах повноважень та у спосіб, що передбачені не лише Конституцією України, а й законами України. Наведена конституційна норма міститься серед базових принципів конституційного ладу України - у розділі I «Загальні засади». Крім того, цю думку підкреслено ще в одній, спеціалізований нормі, яка прямо стосується статусу глави держави: «Президент України на основі та на виконання Конституції і законів України видає укази і розпорядження, які $\epsilon$ обов'язковими до виконання на території України» (частина третя статті 106 Конституції України) [9]. Аналіз цієї конституційної норми не залишає 
сумнівів - Президент України видає укази на основі й на виконання як Конституції України, так і законів України. Видаючи укази, Президент України робить не що інше, як здійснює свої повноваження на основі та на виконання цих двох вищих джерел права.

Тепер другий аспект - як розуміти текст статті 106 Конституції України, де сформульовані повноваження Президента України? У рішенні КСУ від 10.04.2003 р. вказано, що відповідно до Конституції України повноваження Президента України вичерпно визначені Конституцією України, а це унеможливлює прийняття законів, які встановлювали 6 інші його повноваження (права та обов'язки) [10]. Тобто, як випливає із цієї юридичної позиції, законами України не можуть встановлюватися будь-які повноваження глави держави, за винятком тих, що визначені Конституцією України. Ніхто не буде дискутувати з приводу того, що повноваження Президента України вичерпно встановлені в Конституції України, питання в іншому: як методологічно правильно розуміти зміст та обсяг цих конституційних повноважень глави держави? [9].

«Вичерпність» конституційних повноважень Президента України не тотожна переліку формулювань у частині першій статті 106 Конституції України. Президент України здійснює й такі повноваження, які випливають з органічної суті та обсягу перерахованих конституційних повноважень та іманентно $€$ властивими для його конституційної ролі, якщо при цьому вони мають підґрунтя в Законі України та не суперечать фундаментальним конституційним принципам (поділу влади, демократії, поваги до прав людини) [9].

Конституція України - це не лише текст (i контекст), вона $\epsilon$ ціннісним порядком, який має сприйматися системно й цілісно. Саме тому формулювання щодо повноважень глави держави слід сприймати у системному зв'язку з принципами та іншими конституційними нормами, якими визначається статус Президента України, зокрема його ролі як гаранта державного суверенітету, територіальної цілісності України, додержання Конституції України, прав і свобод людини і громадянина [1].

Отже, конституційні повноваження Президента України для реалізації потребують окреслення їх змісту на рівні законів України. Це означає, що вони можуть і не бути відображеними в конституційних форму- люваннях, однак повинні випливати з них та бути спрямованими на досягнення конституційних цілей, виражаючи властивості та органічну сутність відповідних положень Конституції України [9].

Застосування формального підходу щодо наявності у глави держави лише прямо установлених у положеннях Конституції України повноважень може мати надалі досить суттєвий деструктивний вплив на функціонування всієї демократичної системи здійснення державної влади в Україні та унеможливити виконання главою держави його конституційно визначених повноважень [13].

Також необхідно встановити, чи $\epsilon$ серед конституційних повноважень Президента України повноваження, що реалізуються ним у правоохоронній сфері. Слід зазначити, що правоохоронна функція держави полягає в забезпеченні охорони конституційного ладу, прав і свобод громадян, законності та правопорядку. Вона завжди була притаманна державі та $€$ однією з провідних в її діяльності. При цьому роль Президента України в реалізації правоохоронної функції держави $€$ досить важливою, оскільки Президент України $\epsilon$ гарантом додержання Конституції України, прав та свобод людини і громадянина [1]. Отже, до конституційних повноважень Президента України належить вирішення питань у правоохоронній сфері.

Тепер необхідно з'ясувати: чи містить Указ Президента України загрози для поділу влади? Поділ влади $\epsilon$ основним засобом та неодмінною умовою запобігання концентрації влади, тому будь-яке порушення принципу поділу влади, що призводить до ії концентрації, в тому числі суміщення не належних певним органам державної влади функцій, порушує гарантії прав і свобод людини і громадянина [11]. Однак при цьому слід розуміти, що Президент України займає особливе місце в системі органів державної влади та не належить до жодної з їі гілок. Статус Президента України як глави держави вказує на те, що він $\epsilon$ представником усієї держави, важливою ланкою в механізмі «стримувань і противаг» та державної влади загалом, а отже, гарантом і координатором злагодженого, узгодженого, скоординованого, безперебійного функціонування всього державного владного механізму і взаємодії між його головними складниками, уповноваженим за потреби вживати організаційно-правових заходів 
для започаткування в порядку, визначеному Конституцією та законами України, роботи відповідних нових органів, що мають відігравати важливу роль у забезпеченні або виконанні функцій держави [13].

При цьому конституційний припис щодо поділу влади на законодавчу, виконавчу та судову неодноразово розглядався Конституційним Судом України не тільки як такий, що покликаний забезпечувати самостійне виконання державними органами своїх функцій і повноважень, а й утверджувати права і свободи людини і громадянина та забезпечувати стабільність конституційного ладу в державі. В одній зі справ Конституційний Суд висловив таку юридичну позицію: «Щодо тлумачення повноважень Президента та способів їх реалізації, частина друга статті 102 Конституції України проголошує, що Президент $\epsilon$ «гарантом державного суверенітету, територіальної цілісності України, додержання Конституції України, прав і свобод людини і громадянина». За главою держави закріплено широкі повноваження як у вирішенні загальнодержавних проблем, котрі вимагають поєднання політичних, економічних, соціальних та інших аспектів функціонування держави, так, рівнозначно, і в розгляді локальних питань, що стосуються захисту справедливості, прав, свобод та інтересів окремої людини в разі їх порушення будь-ким, у тому числі й державою. Для реалізації цих функцій Президент приймає рішення, які мають силу законодавчих актів, а в разі необхідності - безпосередньо втручається в критичну ситуацію з метою усунення будь-якої загрози для держави та її громадян» [12].

Висновки. У правовій демократичній державі Конституційний Суд покликаний бути останньою барикадою проти зазіхань на Конституцію, їі принципи й цінності. Його завданням насамперед $є$ забезпечення верховенства та правової охорони конституції, припинення дії неконституційних актів, розв'язання конституційно-правових конфліктів, що має важливе значення для загального процесу забезпечення непорушності прав і свобод людини і громадянина, а також функціонування держави на загальнодемократичних конституційних засадах. Винятково важлива роль органу конституційного правосуддя в конституційній державі та завдання, які він виконує, зумовлюють необхідність забезпечити його незалежність. Причому важливим $€$ забезпечення незалежності як органу, так і його членів. Саме від реального стану забезпечення їх незалежності й залежить успішне виконання органом конституційної юрисдикції його завдань та функцій. Однак чи виконує КСУ завдання, що стоять перед ним, та чи не становлять останні рішення КСУ загрозу належному врядуванню та демократичному розвиткові нашої держави? Ці питання у світлі останніх подій стали надзвичайно актуальними. Тому нагальною залишається проблема реформування цієї інституції. У 2016 році, коли розроблявся проект закону «Про Конституційний Суд України», його розробники та Венеціанська комісія, що його розглядала, помилково виходили з презумпції того, що конституційний суддівський корпус буде свідомим щодо своєї ролі та значення у правовій демократичній державі [7].

Оцінюючи виданий Президентом указ № 607/2020 про відсторонення від посади судді КСУ, можна зазначити таке. Чинне законодавство потрібно застосовувати комплексно у своїй нерозривній єдності, як з урахуванням положень Конституції, так і законів України, в тому числі закону про КСУ та КПК, які визначають гарантії суддів КСУ під час здійснення щодо них кримінального провадження.

Оскільки порядок кримінального провадження на території України визначається лише кримінальним процесуальним законодавством України (стаття 1 КПК), Закон України «Про Конституційний Суд України» не може і не повинен урегульовувати питання застосування заходів забезпечення кримінального провадження.

Слід погодитись, що ч. 3 ст. 154 КПК у найзагальніший спосіб визначає повноваження Президента відсторонити від посади в межах кримінального провадження. А саме $\epsilon$ вказівка, що глава держави має такі повноваження виключно щодо «осіб, що призначаються Президентом», та «на підставі клопотання прокурора в порядку, встановленому законодавством».

Перелік осіб, яких призначає на посади глава держави, визначений у ст. $106 \mathrm{Koн}-$ ституції, серед яких $€$ й судді КСУ. Тобто Президент не вийшов за межі своїх повноважень і діяв у межах чинного законодавства, положення якого (Конституція та закони України) потрібно застосовувати у своїй нерозривній єдності. 
Розуміючи, що гарантії суддів КСУ під час здійснення щодо них кримінального провадження натепер $\epsilon$ недосконалими й такими, що потребують подальшого вдосконалення з огляду на особливий статус суддів КСУ, положення ч. 3 ст. 154 КПК визначає, що Президент уповноважений відсторонювати від посади осіб, які призначаються ним, що цілком узгоджується 3 приписами ст. 106 Конституції, яка передбачає, що Президент на основі та на виконання Конституції і законів України видає укази й розпорядження, які $\epsilon$ обов'язковими до виконання на території України.
Без сумніву, зазначений указ формально не $\epsilon$ бездоганним, проте він відповідає меті та завданням Конституції України, зокрема забезпеченню її дієвості у сфері забезпечення правопорядку. Враховуючи, що у правозастосовній діяльності виникають питання щодо тимчасового відсторонення від посади судді КСУ у зв'язку з притягненням його до кримінальної відповідальності, необхідно на законодавчому рівні узгодити між собою положення ст. 149 Конституції, ст. 24 закону «Про Конституційний Суд України» та ч. 3 ст. 154 КПК.

\section{ЛITEPATУPA:}

1. Конституція України від 28.06.1996 p. URL: https://zakon.rada.gov.ua/laws/show/ 254\%D0\%BA/96-\%D0\%B2\%D1\%80

2. Закон України «Про Конституційний Суд України» від 13.07.2017 р. № 2136-VIII. URL: https://zakon.rada.gov.ua/laws/show/2136-19\#Text

3. Кримінальний процесуальний кодекс України від 13.04.2012 p. № 4651-VI. URL: https:// zakon.rada.gov.ua/laws/show/4651-17\#Text

4. Бондаренко Б. Гарантії незалежності Конституційного Суду України. 2017 р. URL: https://www.constjournal.com/wp-content/uploads/issues/2017-3/pdfs/6-bohdan-bondarenkoharantii-nezalezhnosti-suddiv-konstytutsiinoho-sudu-ukrainy.pdf

5. Константий О.В. Суддівський імунітет як гарантія об'єктивного і неупередженого правосуддя в державі. Вісник Верховного Суду України. 2010. № 1 (113). С. 44-47.

6. Ганенко I.C. Імунітет суддів у кримінальному процесі: теоретико-правовий аналіз. URL: https://doi.org/10.32366/2523-4269-2019-69-4-109-114

7. Водянніков О. Королівський крокет, або як відсторонити суддю Конституційного Суду України від посади. URL: http://lb.ua/blog/oleksandr_vodennikov/476220_korolivskiy_kroket_ abo_yak.html

8. Кучинська О. Щодо питання тимчасового відсторонення від посади судді КС на підставі ч. 3 ст. 154 KПК. URL: https://zib.com.ua/ua/146297-schodo_pitannya_timchasovogo_ vidstoronennya_vid_posadi_suddi.html

9. Окрема думка судді Конституційного Суду України Лемака В.В. стосовно Рішення Конституційного Суду України у справі за конституційним поданням 51 народного депутата України щодо відповідності Конституції України (конституційності) Указу Президента України «Про призначення А. Ситника Директором Національного антикорупційного бюро України» від 28 серпня 2020 року № 9-p/2020. URL: https://zakon.rada.gov.ua/laws/ show/na09d710-20\#Text

10. Рішення КСУ від 10.04.2003 р. № 7-рп/2003. URL: https://zakon.rada.gov.ua/laws/ show/v007p710-03\#Text

11. Висновок Конституційного Суду України від 16 грудня 2019 року № 7-в/2019. URL: https://zakon.rada.gov.ua/laws/show/v007v710-19\#Text

12. Ухвала Конституційного Суду України від 8 травня 1997 року № 11-3. URL: https:// zakon.rada.gov.ua/laws/show/vz11u710-97\#Text

13. Окрема думка судді Конституційного Суду України Колісника В.П. стосовно Рішення Конституційного Суду України у справі за конституційним поданням 50 народних депутатів України щодо відповідності Конституції України (конституційності) окремих положень Закону України «Про Національне антикорупційне бюро України». URL: https://zakon.rada.gov.ua/ laws/show/nb11d710-20\#n2 